\title{
Police Role In The Process Of Penal Mediation
}

\author{
Agus Triatmoko ${ }^{1}$ and Anis Mashdurohatun ${ }^{2}$
}

Abstract. Penal mediation settlement of criminal cases into the shape desired by the people involved in the dispute or disputes between community members. This is caused because the penal mediation there is no one party that defeated or won, so hopefully after the settlement with this penal mediation model disputing community members can live in peace side by side back to normal. This study raises the issue. What is the role of the police in the process penal mediation? This study belongs to the species normative legal research. Technic collecting data used is the study of literature. Descriptive analysis method. The results showed that that the implementation of the Police has the authority to conduct penal mediation by Act No. 2 of 2002 on the Indonesian National Police. One form of penal mediation by the police that the decision to terminate the criminal case after the settlement reached through negotiation involving mainly the victims and perpetrators, as well as religious leaders, community leaders and local government representatives.

Keyword: Police; Penal Mediation; Criminal Case.

\section{Introduction}

Penal mediation or also called mediation in criminal cases or mediation in penal matters is a concept that brings the offender to the victim. Therefore, penal mediation is often also referred to as Victim Offender Mediation (VOM), Tater Opfer Ausgleich (TOA), or Offender Victim Arrangement (OVA). ${ }^{3}$ Penal mediation is one method of settling the criminal case is practically implemented by the public when there is a dispute or disputes between community members.

In the Indonesian positive law explicitly penal mediation has not received legal protection. Because basically the regulation of the Criminal Justice System (CJS) Indonesia does not regulate the settlement out of court, resulting in some cases informally been resolved peacefully through the mechanism of customary law, but still in the process to the court in accordance with the regulations of the criminal justice system Indonesia.

The number of cases misdemeanor cases that go to trial have also been mebebani court, both in terms of budget and in terms of public perception of the court. Generally, people do not understand how the process of criminal litigation until it can go to court, which the parties who have authority in each stage, and people have generally only determine whether there is a criminal case only when the case is heard in court. And since they had reached the stage of court proceedings, the public

\footnotetext{
1 Student of Master of Law, Universitas Islam Sultan Agung Semarang email: triatmokoagus87@yahoo.co.id

${ }^{2}$ Lecturer of Faculty of Law Unissula Semarang

${ }^{3}$ Barda Arif Nawawi 2008 Mediasi Penal: Penyelesaian Perkara Pidana di Luar Pengadilan Program Magister Ilmu Hukum Pascasarjana UNDIP p. 3.
} 
spotlight then focused only on the court and demanded that the court consider the public sense of justice. ${ }^{4}$

Over criminal also be a problem tackling criminal offense in Indonesia. Correctional institutions increasingly filled by inmates with various cases backgrounds. It makes the penitentiary as a rehabilitation increasingly inhuman as a result of the lack of facilities due to overcapacity. Even poor prison facilities are often cause conflicts among fellow inmates society institutions that led to the riots.

Among the law enforcement officers who often mediating penal through discretion is the police. ${ }^{5}$ This is because it is based on the provisions of Article 18 of Act No. 2 of 2002 on the Police of the Republic of Indonesia (hereinafter referred to as the Police Law) which states that; (1) For the general interest of the Republic of Indonesia Police officials in carrying out the duties and authority to act according to his own judgment; (2) The provisions referred to in paragraph (1) may be performed in a state that really needs to pay attention to laws and regulations, as well as the Code of Professional Ethics of Indonesian Police.

As explained in the general description of the Police Law, that as the protector, the role of the Indonesian National Police should be developed through the consolidation of the authority to act according to its own assessment in the public interest, so that the protection and service to the community can be implemented as well as possible. ${ }^{6}$ In connection with that, the police practice during this time that did not investigate the case which is too mild nature of the public interest can be seen as an attempt aegis, so that it can continue. Included also in this case the role of policing function builder that grows and develops sociologically in the governance of public life.

Based on the above, it appears that despite the explicit penal mediation is not regulated in the legislation, a provision in the legislation as mentioned above implicitly shows that the completion of the criminal case outside the court process has been given a place. But in essence the police discretionary provisions as mentioned in the above the Police Law has authorized the police in the process of settlement of a criminal case out of court (discretion). In addition, the authority given to the Indonesian National Police as an institution of legal pengak responsible for maintaining security and order implicitly be used as a foothold in resolving a criminal case out of court.

INP today must be a state agency that actually becomes the representation of the community and have a pattern of action and function as social control, the paradigm of partnership, participation, professional, consciousness (not to forward the means of coercion) and the community (not individualistic). It can only be done if the Police seriously implement the strategy set out in the Decree of the Chief of Police No. Pol: SKEP / 737 / X / 2005 on Community Policing Strategy and Policy Implementation.

\footnotetext{
${ }^{4}$ Explanation of the Indonesian Supreme Court Regulation No. 2 Year 2012 concerning limitation adjustment light crime and Total Fines in Criminal Law.

${ }^{5}$ In addition to the police some institutions can also mediate penal as shown research Unu Putra Herlambang Nyoman Serikat P.J. dan A.M.Endah Sri Astuti 2012 Penyelesaian Perkara Tindak Pidana Pers Melalui Dewan Pers Sebagai Lembaga Mediasi in https://media.neliti.com/media/publications/19532-ID.pdf Accessed on July 152018

${ }^{6}$ See the explanation of Article 18 of Act No. 2 of 2002 on the Indonesian police.
} 
Models of community policing that has been adopted by the police on 13 October 2005 was believed to be a new strategy of policing in Indonesia.

CBP was born due to the awareness of police chiefs that the ways of policing carried out during this time is no longer effective in tackling crime and social order conditions faced by society today (SKEP the background to the Chief of Police). Program Community policing has priority in the problem solving security and order are done together equal with the community through a partnership forum (consultation), and does not make public just informant, but along with the police are key actors, any decision on issues arising in connection with public order and security.

Based on the above description of the background, the authors will examine the role of the police in penal mediation process.

\section{Research Methods}

This type of research conducted by the author belongs to the species juridical legal research is research done by researching library materials is a secondary data and research are also called legal research literature. ${ }^{7}$ Normative legal approach is done by identifying and conceptualize law as norms, rules, regulations, laws apply to a particular time and place as the product of a particular sovereign state power which is then often referred to as a doctrinal legal research. According Soekanto, data collection techniques consists of the study of literature; interview, and a list of questions (questionnaire). ${ }^{8}$ This study uses literature study.

\section{Results And Discussion}

Police is one of the state institutions which have a duty to create and maintain security. According Satjipto Raharjo, the police are an instrument of state in charge of maintaining security and public order, provide shelter, and provide protection to the public. ${ }^{9}$ Furthermore Satjipto Bitner Raharjo quoting the opinion states that if the law aims to create order in society, including the fight against crime. Finally the police who will determine concretely what is referred to as the enforcement order. ${ }^{10}$

While police agencies is a government organ which established as an institution and given authority to carry out its functions under the legislation. ${ }^{11}$ Furthermore, Article 5 of the Police Law states that: 1) The Indonesian National Police is a tool that plays a role in maintaining state security and public order, enforcing the law, and to provide protection, shelter and services to the community in order to maintaining security in the country. 2) The Indonesian National Police is the national police which is a unity in carrying out the role as referred to in paragraph (1).

In carrying out the mandate of the law, the police made a breakthrough berbagasi program, one program Community Oriented Policing (COP). According Suparman

\footnotetext{
${ }^{7}$ Ronny Hanitijo Soemitro 1988 Metodologi Penelitian Hukum Dan Jurimetri Jakarta: Ghalia p. 9.

${ }^{8}$ Soekanto 1986 Pengantar Peneltian Hukum Yogyakarta: Universitas Indonesia (UI) Press p.52

${ }^{9}$ Satjipto Raharjo 2009 Penegakan Hukum Suatu Tinjauan Sosiologis Gentang Publisher Yogyakarta p. 111.

${ }^{10}$ lbid. p. 117

${ }^{11}$ Sadjijono 2008 Etika Profesi hokum Suatu Telaah Fllosofis Terhadap Konsep dan Implementasi Kode Etik Profesi Polri FH Universitas Parahyangan Bandung p. 52- 53
} 
Marzuki Program Community Oriented Policing (COP) is a means and tool of effective cooperation for resolving the problems of safety and security and order in society. Criminal and legal cases that occur when resolved by an instrument of customary law and cultural norms in society. In this context, in addition to running a formal positive law enforcement, police officers can also be developed as an informal law enforcement in favor of the wider community. ${ }^{12}$

Police want through community policing, it will be able to reduce the number of crime and make the institution as the spearhead of the Police. The existence of community policing also to be able to bridge the issues that arise in the community so as to avoid a prolonged polemic. There was also the presence of community policing can create a sense of security in society.

If this policy is carried out by all units of the Police in the country cantonal police duties future it will be easier as close to the community. The purpose for establishing such closeness will be assisting the police in the neighborhood. Proximity to the community is assisting the police.

Community police duties in direct contact with people's lives is a form of civilian police to maintain security and order in the community together. In addition, the direct settlement to the problems in the middle of the community by the police will suppress the interference level of security and order.

The involvement of community policing in the resolution of criminal cases through mediation conducted by approaching the parties involved in a criminal incident. In carrying out the function of the mediator, policing still performed the role of law enforcement by holding on principles such as: 1) Giving priority to the interests of victims of the offender; 2) Taking into account the sociological aspectie the balance between criminalization and social relationships; and 3)Give understanding to the victims of the consequences of the sentence being served to the perpetrator's family.

Penal mediation by the police in finalizing criminal cases initiated since the report came in. After the complainant reported to IFMS (Integrated Police Service Center), which is implementing elements of the main tasks in the field of police services. The report by the reporting is done orally or in writing. The next part of IFMS continue to report to the Criminal. Before filing, call the community police detectives then requested consideration of the position of the case.

Thus, in criminal cases are resolved through penal mediation has unique characteristics in its handling in the police. Reports that were not done first filing, but preceded by listening to the consideration of the community police and the complainant and reported. Therein lies the discretionary authority of the police have started to function.

The next community policing, in the approach to the perpetrators of criminal mediation process in cases handled by explaining to the actors on the rights and obligations such as by providing an understanding among others: 1) Taking into account the sociological aspect ie the balance between criminalization and social relationships; 2) Give sense to the perpetrators of the inflicted caused by the offender; 3) Provide understanding of inflicted losses cost the offender.

\footnotetext{
${ }^{12}$ Eko Prasetyo dkk. 2004 Peran Polisi dalam konflik sosial-Politik di Indonesia Yogyakarta:Pusham Universitas Islam Indonesia p. 92.
} 
During this time, the presence of the police community policing is not a single fighter, but aided by various stakeholders in the community, such as device FPKM, religious leaders, community leaders, traditional leaders, the victim and the offender as parties in a criminal case. Therefore, success in completing tasks as mediator criminal case because of the support of these parties.

Completion of criminal cases through penal mediation law must respect social norms / customs and meets the principles of justice. Therefore, in some areas of penal mediation utilizing traditional institutions, such as research ditunujukkan by Lilik Mulyadi, ${ }^{13}$ Where penal mediation settlement was not formally facilitated by the state, but through the mechanism of traditional institutions (Justice Gampong, Culture Bakar Batu, Institute Begundem and awig awig), because during the penal mediation is not regulated at the level of the Act but is known on a limited basis through the discretion of law enforcement and only partial.

Empower members FKPM policing and play in their respective areas to be able to identify criminal cases that have little material loss and allow it to be resolved through penal mediation. For cases that have been completed through penal mediation to no longer be touched by any other legal action is counter productive to the purpose of community policing.

In the order under the law for settling disputes out of court through penal mediation stipulated in the Letter of the Chief of Police No. Pol: B / 3022 / XII / 2009 / SDEOPS 14 December 2009 on the Handling of Cases Through the Alternative Dispute Resolution (ADR) which was later affirmed again Letter telegram Police Kabareskrim No.Pol .: STR / 583 / VIII / 2012 on Implementation Guidelines for the Alternative Dispute Through Case penaganan Reosuliton (ADR) .Serta Police Chief Regulation of the Republic of Indonesia Number 7 of 2008 on Basic Guidelines and Implementation Strategy Community Policing In Implementation of Police Duties.

Penal mediation mechanism is currently not regulated in the Criminal Code, the Criminal Code and the Act itself. Therefore, in the future (ius contituendum) should at least be considered in more depth in what conditions the penal mediation should be regulated is regulated in the Criminal Code, Criminal Procedure Code, the Act itself, the Regulation under the Act or the Rules of the Supreme Court.

In practice, the law is applied despite penal mediation legislation has not regulated then there has been a paradigm shift in their quasi private law into public law and described the research results that agree if the penal mediation conducted. However, against the penal mediation process performed relative who vote in the Police and the Courts are relatively balanced. Penal mediation regulation should set a limited manner in the event that the case of what can be done through penal mediation. Description of the research mentioned some things that can be arranged in a limited performed penal mediation in the form of a mild case of theft, the case is personal, the case of children, a mild case of theft, personal, and things that are done by children as well as cases of domestic violence.

\footnotetext{
${ }^{13}$ Lilik Mulyadi 2013 Mediasi Penal dalam Sistem Peradilan Pidana Indonesia: Pengkajian Asas Teori dan

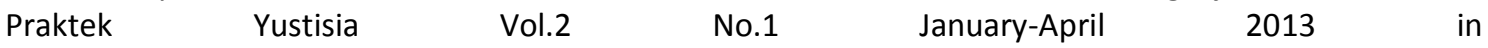
https://jurnal.uns.ac.id/yustisia/article/viewFile/11054/9892 Accessed on July 152018
} 
General Court considered relatively more appropriate to hear the case of theft light, the case is personal, children cases, cases, cases of theft lightweight, personal, and things that are done by children as well as cases of domestic violence compared with traditional justice and formed a separate judicial body. The researcher argues that basically does not negate the criminal element for actors, but for certain crimes such as those involving children should be peace for the perpetrators who are still children are not entangled with the law or does not deal with the court that would lead to the child being labeled as criminals.

In the judicial process should run a process that is expected is a process that can recover, which means that the case only too well handled by law enforcement officers who have the intention, interest, dedication, understanding the problem child and had attended training restorative justice and detention carried out as a last option with regard to the principles basic principles and conventions on the rights of children who have been adopted into law on child protection. The above provisions merely give the possibility of resolving criminal cases out of court, but not yet a penal mediation as described above.

Settlement out of court under Article 82 of the Criminal Code above does not describe explicitly the possibility of an amicable settlement or mediation between the offender and the victim (especially in matters of redress or compensation) which is means of transfer / diversion (Means of diversion) for the termination of prosecution and criminal punishment. Article 82 of the Criminal Code is the reason eraser prosecution, but not because it has any indemnity / compensation to the victim, but only because it has to pay the maximum fine threatened. The completion of the criminal case by giving compensation to the victim, it is possible in case the judge would convict parole (Article $14 \mathrm{c}$ of the Criminal Code). It is noteworthy, conditional criminal provisions in the Criminal Code even this is still oriented to the interests of the perpetrator (Offender oriented), not victim-oriented.

Police can use its authority as law enforcement in achieving justice for victims and perpetrators. In this case, the police can use the discretionary authority granted by the legislation. In harmony with the opinion Pound Roescoe ${ }^{14}$ that discretion as law enforcement methods that effectively and efficiently into the police authority to make decisions or choose a variety of actions in resolving issues of law violations or criminal cases are handled.

In essence, the rule of law is a process of adjustment between values and actual behavior patterns, which aims to achieve peace, so that the main task of law enforcement is to achieve justice. Discretion in the field of law enforcement can only be done by the investigator therefore required in law enforcement people who have konpetensi, intelligence, and skill in action. In the case of the investigation of discretion is not familiar among the police, for the implementation of discretionary powers possessed by the police during police investigations are often carried out when faced with problems to be solved immediately and so forth. The benefits of their discretion to make the operations of the police to be more efficient and effective,

\footnotetext{
${ }^{14}$ In Barhamudin 2014 “Diskresi Polisi Dalam Penyidikan Perkara Pidana Jurnal SOLUSI VOLUME. 5. No. II May 2014
} 
Penal mediation as a mechanism for the implementation of discretion by the police according to Sahuri Lasmidi ${ }^{15}$ the implementation of the reform ideas of criminal law (penal reform), and is associated with a matter of pragmatism. Background ideas "penal reform" among other ideas the protection of victims, the idea of harmonization, the idea of restorative justice, the idea of overcoming the rigidity / formalities in the existing system, the idea of avoiding the negative effects of the criminal justice system and criminal system that exists today, especially in the search for alternatives to imprisonment (alternative to Imprisonment / alter-native to custody). Background pragmatism among others to reduce stagnation or accumulation of cases (the problems of court case overload), to simplify the judicial process.

\section{Closing}

\subsection{Conclusion}

Based on the problems and the above discussion, it can be the authors conclude about Police role in penal mediation process is one of the responsibilities born of Act No. 2 of 2002 on the Indonesian National Police that gives freedom to the police at the time of execution of all duties, responsibilities and authority in law enforcement. In exercising these powers, the role and position of the police as an investigator has authorized the police to conduct discretion, so that the investigating officer can use discretion in performing their duties.

\section{2. Suggestions}

Based on the results of the discussion above, can the authors suggest the following:

- To the police, in taking decisions discretion in resolving criminal cases to pay attention to the sense of justice both parties litigant.

- To the general public, in dealing with criminal matters in order to take the middle path that most have a positive impact.

\section{Bibliography}

[1] Barda Arif Nawawi 2008 Mediasi Penal: Penyelesaian Perkara Pidana di Luar Pengadilan Program Magister Ilmu Hukum Pascasarjana UNDIP.

[2] Barhamudin 2014 "Diskresi Polisi Dalam Penyidikan Perkara Pidana Jurnal SOLUSI VOLUME. 5. No. II May 2014

[3] Eko Prasetyo dkk. 2004 Peran Polisi dalam konflik sosial-Politik di Indonesia Yogyakarta: Pusham Universitas Islam Indonesia.

[4] Lilik Mulyadi 2013 Mediasi Penal dalam Sistem Peradilan Pidana Indonesia: Pengkajian Asas Teori dan Praktek Yustisia Vol.2 No.1 Januari-April 2013 dalam https://jurnal.uns.ac.id/yustisia/article/viewFile/11054/9892 accessed on 15 July 2018

[5] Indonesian Supreme Court Regulation No. 2 of 2012 concerning limitation adjustment light crime and Total Fines in Criminal Law

\footnotetext{
15 Sahuri Lasmadi Mediasi Penal Dalam Sistem Peradilan Pidana Indonesia in https://online-
} journal.unja.ac.id/index.php/jimih/article/view/530/484 Accessed on July 152018. 
[6] Ronny Hanitijo Soemitro 1988 Metodologi Penelitian Hukum Dan Jurimetri Jakarta: Ghalia.

[7] Sadjijono 2008 Etika Profesi hukum Suatu Telaah Fllosofis Terhadap Konsep dan Implementasi Kode Etik Profesi Polri FH Universitas Parahyangan Bandung.

[8] Sahuri Lasmadi Mediasi Penal Dalam Sistem Peradilan Pidana Indonesia in https://online-journal.unja.ac.id/index.php/jimih/article/view/530/484 accessed on 15 July 2018.

[9] Satjipto Raharjo 2009 Penegakan Hukum Suatu Tinjauan Sosiologis Gentang Publisher Yogyakarta.

[10] Soekanto 1986 Pengantar Peneltian Hukum Yogyakarta: Universitas Indonesia (UI) Press.

[11] Act No. 2 of 2002 on Police of Republic Indonesia.

[12] Unu Putra Herlambang Nyoman Serikat P.J. dan A.M.Endah Sri Astuti 2012 Penyelesaian Perkara Tindak Pidana Pers Melalui Dewan Pers Sebagai Lembaga Mediasi dalam https://media.neliti.com/media/publications/19532-ID.pdf accessed on 15 July 2018 